International Journal of Current Advanced Research

ISSN: O: 2319-6475, ISSN: P: 2319 - 6505, Impact Factor: SJIF: 5.995

Available Online at www.journalijcar.org

Volume 6; Issue 4; April 2017; Page No. 3275-3276

DOI: http://dx.doi.org/10.24327/ijcar.2017.3276.0245

Research Article

\title{
A STUDY TO ASSESS THE KNOWLEDGE REGARDING OBESITY AMONG HOUSE WIVES
}

\section{Jamuna.S B}

Sree Balaji College of Nursing, Bharath University, Chrompet, Chennai

\begin{tabular}{ll}
\hline A R T I C L E I N F O & A B S T R A C T \\
\cline { 1 - 2 } Article History: & $\begin{array}{l}\text { Obesity is the most prevalent form of malnutrition in both developed and developing } \\
\text { countries and affecting children as well as adult is replacing the more traditional public } \\
\text { health concerns obesity and overweight are the fifth leading cause of death worldwide. As } \\
\text { Received } 8^{\text {th }} \text { January, } 2017\end{array}$ \\
$\begin{array}{l}\text { obesity is the key risk factor in natural history of other chronic non communicable diseases. } \\
\text { Accepted } 22^{\text {nd }} \text { March, } 2017\end{array}$ & $\begin{array}{l}\text { Majority 12(40\%) of them had inadequate knowledge } 9(30 \%) \text { of them had moderate } \\
\text { knowledge } 9(30 \%) \text { of them had adequate knowledge about obesity among housewives. }\end{array}$
\end{tabular}

Key words:

Obesity, Malnutrition

Copyright $₫ 2017$ Jamuna.S B. This is an open access article distributed under the Creative Commons Attribution License, which permits unrestricted use, distribution, and reproduction in any medium, provided the original work is properly cited.

\section{INTRODUCTION}

Obesity is a complex condition, one with serious social and psychological dimensions, that affects virtually all age and socio economic groups and threatens to overwhelm both developed and developing countries. As in developed societies, the risk for obesity in developing countries is also strongly influenced by diet and lifestyles, which are changing dramatically as a result of the economic and nutrition transition. Obesity is a key risk factor in the natural history of non communicable diseases like hypertension and diabetes mellitus.

According to WHO global estimates, about $13 \%$ of the world's adult population (11\% man and $15 \%$ women) were obese in 2014. Prevalence of obesity varies according to age, sex and religion. In India the percentage of even married women age 15-49 years who are overweight or obese increased from 11\% I national family health survey (NFHS) 2 to $15 \%$ in NFHS - 3. The percentage of women who are overweight or obese is highest in Punjab, followed by Kerala and Delhi.

\section{METHODOLOGY}

Non experimental research design and Descriptive survey approach was used for this study. 30 samples were from the, pallavaram urban community which situated $4 \mathrm{~km}$ away from our college. This area was selected because of getting expected samples. The tool for the study was structured interview schedule.

\section{*Corresponding author: Jamuna.S B}

Sree Balaji College of Nursing, Bharath University,

Chrompet, Chennai

\section{Data Collection}

The investigator explained the procedure and purpose to data collection to the sample. Initially their consent was obtained then the interview schedule was performed by the investigator to the sample.

\section{Scoring Key}

- 0 -- Mark given for wrong answer.

- 1 -- Mark given for correct answer

\section{RESULTS}

The study findings revealed that;

- Majority 17 (57\%) of them belongs to the age group of $35-40 y r s$

- $3(10 \%) 0 \mathrm{f}$ them belongs to the age group of $41-45 \mathrm{yrs}$

- $10(33 \%)$ of them belongs to the age group of $46-50 \mathrm{yrs}$

- $12(40 \%)$ of them were illiterate,

- $11(37 \%) 0$ of them were primary and secondary

- $7(23 \%)$ of them were graduate

- Majority $15(50 \%)$ of them were Hindu

- $10(33 \%)$ of them were Christian

- $5(17 \%)$ of them were Muslim

- Majority $20(66 \%)$ of women lives in nuclear family.

- $5(17 \%)$ of women lives in joint family.

- $5(17 \%)$ of women lives in extended family.

- Majority $12(40 \%)$ of them earn Rs. 7000-9000

- $9(30 \%)$ of them earn Rs. 5000-7000

- $\quad 9(30 \%)$ of them earn Rs.3000-5000

- Majority $15(50 \%)$ of them through media

- $8(27 \%)$ of them through newspaper

- $7(23 \%)$ of them through neighbors 
- Majority $12(40 \%)$ of them had inadequate knowledge

- $9(30 \%)$ of them had moderate knowledge

- $\quad 9(30 \%)$ of them had adequate knowledge about obesity

Percentagae Distribution of Knowledge

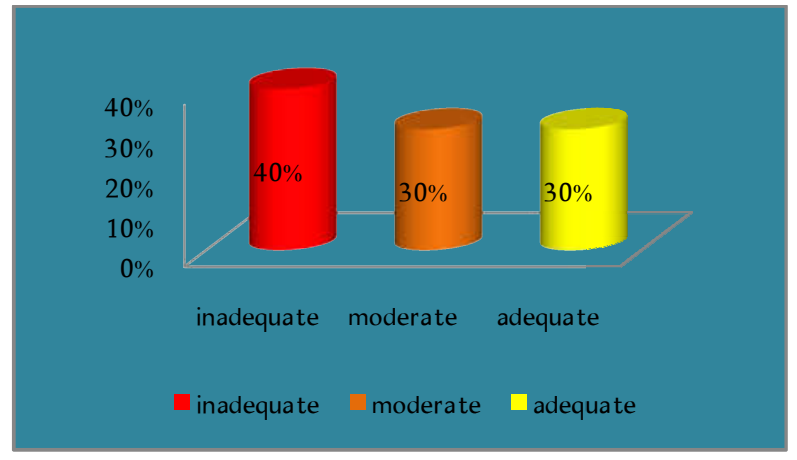

The above figure represents the percentage distribution of level of knowledge

- Majority $12(40 \%)$ of them had inadequate knowledge

- $9(30 \%)$ of them had moderate knowledge

- $9(30 \%)$ of them had adequate knowledge about obesity

\section{CONCLUSION}

The study was to assess the knowledge on obesity among housewives's age group of (35-50years) in a selected urban community. They are selected study is pallavaram urban community in which 30 convenient samples were taken and the questionnarie was prepared and individual were interviewed after obtaining their consult and then it was analyzed.

\section{Bibliography}

Marcia stanhope"Text book of public health nursing" $8^{\text {th }}$ edition, Elsevier publishers.

Sunita "Text book of community health nursing "CBS publishers \& distributers.

K. park "Text book of preventive and social medicine". $12^{\text {th }}$ edition, banarsidas bhanot publishers-2013.

Kasthuri Sundhar Rao" Textbook of community health nursing "published by ecumenical book services.

Wolter kluwer "Text book of community medicines" chief editor, Jaypee publishers Chennai.

Clement "Text book of manual and community health nursing" Jaypee brother's publishers, Newdelhi.

Clement "Text book of basic concepts and community health nursing" $2^{\text {nd }}$ edition, Jaypee brother's publishers (P) Ltd, Chennai.

James F.Mckenzie. Robert R. Pinger. Jerome E. Ketocki "Text book of introduction of community health" $4^{\text {th }}$ edition, Jones and Bargett publishers.

SR. Banergee "Text book of community and social pediatrics" $2^{\text {nd edition }}$, Jaypee brothers publishers (P) ltd, Chennai.

\section{How to cite this article:}

Jamuna.S B (2017) ' A Study To Assess The Knowledge Regarding Obesity Among House Wives', International Journal of Current Advanced Research, 06(04), pp. 3275-3276.

DOI: http://dx.doi.org/10.24327/ijcar.2017.3276.0245 